\title{
Hydrologic behaviour of Tapi river catchment using morphometric analysis
}

\author{
*Vishal K. Ingle, A. K. Mishra, A. Sarangi, D. K. Singh and V. K. Seghal ${ }^{1}$ \\ Division of Agricultural Engineering, Indian Agricultural Research Institute, New Delhi -110012, INDIA \\ ${ }^{1}$ Division of Agricultural Physics, Indian Agricultural Research Institute, New Delhi -110012, INDIA \\ *Corresponding author. E-mail: vishal4644@gmail.com
}

Received:Ferbuary 08, 2014; Revised received: August 20, 2014 ; Accepted: October 06, 2014

\begin{abstract}
The study area Tapi River catchment covers 63,922.91 Sq.Km comprising of 5 five Sub-catchments: Purna river catchment (18,473.6 sq.km) Upper Tapi catchment (10,530.3 sq. km), Middle Tapi catchment (4,997.3 sq km), Girna river catchment (10,176.9 sq.km) and lower Tapi catchment (19,282.5 sq.km.). The drainage network of 5 Sub -catchments was delineated using remote sensing data. The morphometric analysis of 5 Sub-catchments has been carried out using GIS softwares - ArcMap. The drainage network showed that the terrain exhibits dendritic to sub-dendritic drainage pattern. Stream orders ranged from sixth to seventh order. Drainage density varied between 0.39 and $0.43 \mathrm{~km} / \mathrm{km}^{2}$ and had very coarse to coarse drainage texture. The relief ratio ranged from 0.003 to 0.007 . The mean bifurcation ratio varied from 4.24 to 6.10 and falls under normal basin category. The elongation ratio showed that all catchment elongated pattern. Thus, the remote sensing techniques proved to be a competent tool in morphometric analysis.
\end{abstract}

Keywords: Catchment, Geomorphology, Shape parameters, Stream network, Tapi river basin

\section{INTRODUCTION}

The response of a particular watershed to different hydrological processes and its behaviour depends upon various physiographic, hydrological and geomorphological parameters. Though these are watershed specific and thereby unique, the characterization of a watershed provides an idea about its behaviour. Hydrologists attempted to relate the hydrologic response of watersheds to watershed morphologic characteristics. Computation of watershed morphological characteristics is a prerequisite to further detailed hydrological analysis of the watershed. The hydrological response of a river basin can be interrelated with the physiographic characteristics of the drainage basin, such as size, shape, slope, drainage density and size, and length of the streams etc. (Mishra and Rawat, 2012; Kanth and Hassan, 2012). Hence, morphometric analysis of a watershed is an essential first step, toward basic understanding of watershed dynamics. Watershed prioritization is the ranking of different sub - watersheds of a watershed according to the order in which they have to be taken for treatment and soil conservation measures. Morphometric analysis could be used for prioritization of micro-watersheds by studying different linear and aerial parameters of the watershed even without the availability of soil maps (Biswas et al., 1999). Watershed characterization involves measurement of parameters that influence the characteristic behaviour of a watershed whereas analysis aims at the critical study of these parameters to arrive at conclusions on watershed response and behaviour. Watershed management requires physiographic information for watershed prioritization and implementation of soil and water conservation measures. The present study of investigation has set the following as its aim and fulfils the objectives:

To extract and delineate drainage morphometric characteristics (Linear, Aerial and Relief from the DEM, Analyse the linear, areal and relief aspects of the study area, Bring out the form and processes, and Finally assess the morphometric characteristics of the Tapi river catchment. important watershed morphometric characteristics included in the study are: Area of watershed, perimeter, Bifurcation ratio, Elongation ratio,Circulatory ratio, Form factor, Stream order, Drainage density, Average slope of watershed, Drainage texture, Constant channel maintenance etc.

Description of the study area : Location, topography, climate and Drainage basins of Tapi. Tapi Basin is falling under physiographic division(s) of Western Ghats, Satpura range, Deccan plateau. The geographical extent of the Tapi Basin is within the longitude $72.6^{\circ}$ to $78.2^{\circ} \mathrm{E}$ and latitude $19.9^{\circ}$ to $22.0^{\circ} \mathrm{N}$, (Fig.1) covering an area of 63,922.91 Sq. Km, falling in 136 of Survey of India toposheets. The area is covered under 3 state (s) (Gujarat, Madhya Pradesh, Maharashtra) and 19 districts (Jalgaon, Betul, Nashik, Dhule, Narmada, Aurangabad, Jalna, Barwani, Akola,Washim, Bharuch, Nandurbar, East Nimar, Amravati, Buldana, West Nimar, Harda, Surat and, Dangs). 
Geomorphology: Entire Tapi river basin is bounded on the north by the Satpura range, on the east by the Mahadeo hills, on the south by the Ajanta range and the Satmala hills and on the west by the Arabian Sea. The culturable area of the basin is about 4.29 Mha. The forest cover is about $25 \%$ of the area in the basin. Physiographically, the area is a basaltic landscape with major physiographic units of plateau lands, escarpments, hills, piedmont plains, colluvio-alluvial plains and valley plains. The entire Tapi basin can be divided in five Sub-catchments: purna river catchment (C1) 18,473.6 sq.km, Upper Tapi catchment (C2)10,530.3 sq. km, Middle Tapi catchment (C3) 4,997.3 sq km, Girna river catchment (C4) 10,176.9 sq.km and lower tapi catchment (C5) 19,282.5 sq.km., The annual rainfall for the upper, middle, and lower Tapi basins for an average year is $935.55 \mathrm{~mm}, 631.5 \mathrm{~mm}$, and $1,042.33 \mathrm{~mm}$ respectively.

Topography: The Tapi basin has two well-defined physical regions, viz., the hilly regions and the plains. The hilly regions cover the Satpura, the Satmala, the Mahadeo, the Ajanta and the Gawilgarh hills and are well forested. The plains cover the Khandesh plains which are broad and fertile areas suitable for cultivation. The culturable area of the basin is considered as the total of the land under miscellaneous crops and trees, current fallows, other fallows, culturable wasteland and net area sown. The basin in Madhya Pradesh is mostly covered with Deccan trap lava flows. The other formations found in the basin are alluvium, lower Gondwana, Cuddapah system, Bijawar series, and granites gneiss. Most of the area of Tapi basin falling within Maharashtra state is full of cuts and valleys. Lands on the right side of the river lying on southern slopes of Satpura hills consist of black soils. The soil cover is deep and rock is found at greater depths.

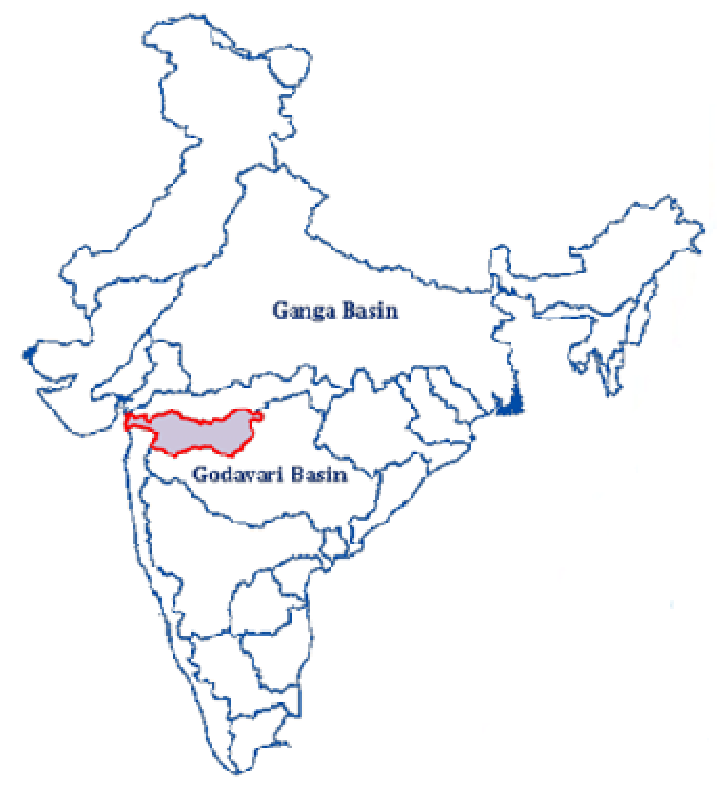

Lands on the left side of the river on northern slopes of Sahyadri consist mainly of dykes and red murrum soil and are rocky in most parts.

\section{MATERIALS AND METHODS}

In the present study, the maps showing image details have been prepared from SRTM digital elevation model. These satellite images have been geo-referenced and merged using Image Processing software ArcGIS (V 9.3) and the thus merged data were used in the study. The drainages have been delineated using satellite data and Survey of India (SOI) toposheets have been used as a reference. Field work has been carried out. The morphometric parameters considered for the analysis are summarized in detail in Table 1 . GIS softwares like ArcMap (V 9.3) have been used for digitization and computational purpose and also for output generation.

Digital elevation model: Topography is defined by a Degital Elevation Model (DEM) that describes the elevation of any point in a given area at a specific spatial resolution. A $90 \mathrm{~m}$ by $90 \mathrm{~m}$ resolution DEM (Fig. 4) was downloaded from SRTM (Shuttle Radar Topography Mission) website.

The DEM was used to delineate the watershed and to analyze the drainage patterns of the land surface terrain. The parameters such as slope gradient, slope length of the terrain (Fig. 6), and the stream network characteristics such as channel slope, length, and width were derived from the DEM.

\section{RESULTS AND DISCUSSION}

The present study emphasizes the use of satellite remote sensing for morphometric analysis.

Watershed delineation: Watershed is a natural hydrological entity from which surface runoff flows to

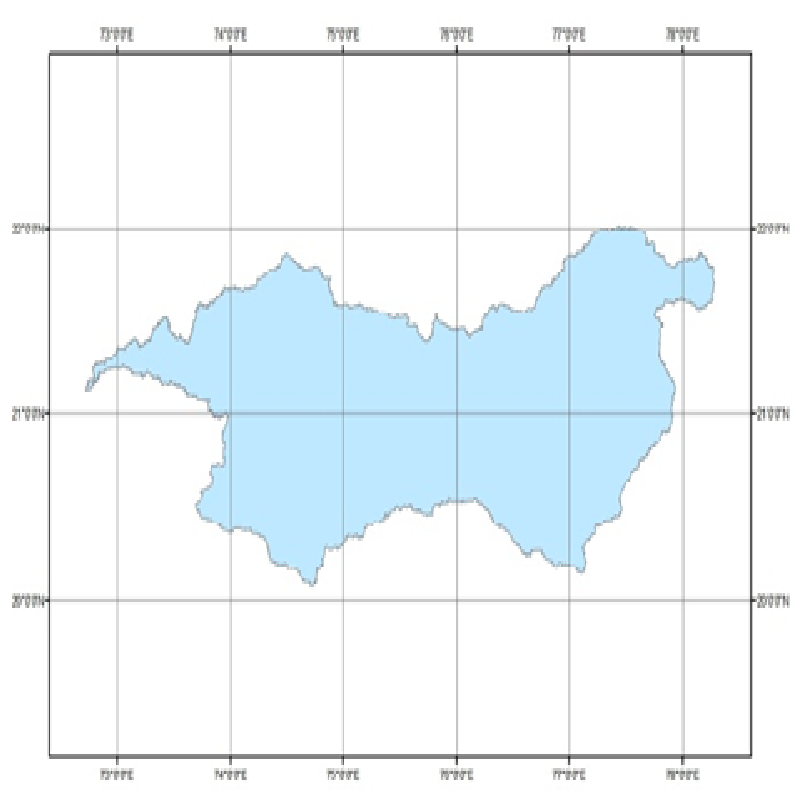

Fig. 1. Location of Tapi river basin in India 
Table 1. Morphometric parameters and their formulae used.

\begin{tabular}{|c|c|c|c|}
\hline S.No. & Morphometric parameters & Formula & Reference \\
\hline 1 & Stream Order & Hierarchical & Strahler(1964) \\
\hline 2 & Stream Length, Km (Lu) & Length of stream & Horton(1945) \\
\hline 3 & Mean stream length (Lsm) & $\begin{array}{l}\mathrm{Lsm}=\mathrm{Lu} / \mathrm{Nu} \\
\text { Where, } \mathrm{Lu}=\text { total stream length of order'u' } \\
\mathrm{Nu}=\text { Total number of stream segments of order' } \mathrm{u} \text { ' }\end{array}$ & Strahler(1964) \\
\hline 4 & Stream Length ratio (RL) & $\begin{array}{l}\mathrm{RL}=\mathrm{Lu} /(\mathrm{Lu}-1) \\
\text { Where, } \mathrm{Lu}=\text { Total stream length of order'u' } \\
\mathrm{Lu}-1=\text { total no of stream segments of its next } \\
\text { lower order }\end{array}$ & Horton(1945) \\
\hline 5 & Bifurcation ratio $(\mathrm{Rb})$ & $\begin{array}{l}\mathrm{Nb}=\mathrm{Nu} /(\mathrm{Nu}+1) \\
\mathrm{Where}, \mathrm{Nu}=\text { Total stream length of order' } \mathrm{u} \\
\mathrm{Nu}+1=\mathrm{Number} \text { of segments of next higer order }\end{array}$ & Schumn $(1956)$ \\
\hline 6 & Mean bifurcation ratio(Rbm) & Average of bifurcation ration of all orders & Strahler(1957) \\
\hline 7 & $\begin{array}{l}\text { Lenth of main channel }(\mathrm{Lm}) \\
\mathrm{Km}\end{array}$ & $\begin{array}{l}\text { Length along longest water course form the } \\
\text { outflow point of designated sub-basin to the upper } \\
\text { limit of catchment boundary }\end{array}$ & Horton(1945) \\
\hline 8 & Drainage Density (Dd) & $\begin{array}{l}\mathrm{Dd}=\mathrm{Lu} / \mathrm{A} \\
\text { Where, } \mathrm{Lu}=\text { Total stream length of all orders, } \mathrm{km} \\
\mathrm{A}=\text { Area of the Basin, } \mathrm{km} 2\end{array}$ & Horton(1932) \\
\hline 9 & Length of overland flow ( $\mathrm{Lg}$ ) & $Z_{g}=\frac{1}{D d^{2}}$ & Horton(1945) \\
\hline 10 & Basin length (Lb) Km & $\begin{array}{l}\text { Where, Dd=Drainage Density } \\
\text { Distance between outlet and farthest point on } \\
\text { basin boundary }\end{array}$ & Horton(1945) \\
\hline 11 & Basin perimeter $(\mathrm{P}) \mathrm{Km}$ & $\begin{array}{l}\text { Length of watershed divide which surround the } \\
\text { basin }\end{array}$ & Horton(1945) \\
\hline 12 & Fineness ratio (Rfn) & $\begin{array}{l}\mathrm{Rfn}=\mathrm{Lb} / \mathrm{P} \\
\text { Where, } \mathrm{Lb}=\text { Basin length, } \mathrm{km} \\
\mathrm{P}=\text { Basin perimeter, } \mathrm{km}\end{array}$ & Melton(1957) \\
\hline 13 & Basin/drainage area $(\mathrm{A})$ & $\begin{array}{l}\text { Area enclosed within the boundary of watershed } \\
\text { divide }\end{array}$ & Horton(1932) \\
\hline 14 & $\begin{array}{l}\text { Constant of channel mainte- } \\
\text { nance }(C)\end{array}$ & $\begin{array}{l}\mathrm{C}=1 / \mathrm{D} \\
\mathrm{D}=\text { Drainage Density }, \mathrm{km} / \mathrm{km}^{2}\end{array}$ & Horton(1932) \\
\hline 15 & Stream frequency $(\mathrm{Fs})$ & $\begin{array}{l}\mathrm{Fs}=\mathrm{Nu} / \mathrm{A} \\
\text { Where, } \mathrm{Nu}=\text { Total number of stream segments of } \\
\text { all order } \\
\mathrm{A}=\text { Area of the Basin, } \mathrm{km}^{2}\end{array}$ & Horton(1932) \\
\hline 16 & Circulatory ratio $(\mathrm{Rc})$ & $\begin{array}{l}\mathbb{R} c=2 \pi \frac{A}{P^{2}} \\
\text { Where, Rc=Circularity Ratio } \\
\text { A=Area of the basin, } \mathrm{km}^{2}\end{array}$ & Miller(1953) \\
\hline 17 & Elongation ratio $(\mathrm{Re})$ & $\begin{array}{l}\mathrm{Re}=\frac{2 R}{\mathrm{Lb}} \\
\mathrm{A}=\text { Area of the basin, } \mathrm{km}^{2} \\
\mathrm{R}=\text { radius of circle whose area equal to basin area } \\
\mathrm{Lb}=\text { Basin length }\end{array}$ & Schumm(1956) \\
\hline 18 & Form Factor(Rf) & $\begin{array}{l}\mathbb{R f}=\frac{A}{Z b^{2}} \\
\mathrm{~A}=\text { Area of the basin, } \mathrm{km}^{2} \\
\mathrm{Lb}=\text { Basin length }\end{array}$ & Horton(1932) \\
\hline
\end{tabular}


Table 1. Contd.

\begin{tabular}{|c|c|c|c|}
\hline 20 & Total relief $(\mathrm{H})$ & $\begin{array}{l}\mathrm{H}=\text { is the maximum vertical distance between the } \\
\text { lowest (outlet) and the highest (divide) points in the } \\
\text { watershed. Relief is an indicative of the potential en- } \\
\text { ergy of a given }\end{array}$ & \\
\hline 21 & Relief ratio $(\mathrm{Rh})$ & $\begin{array}{l}\mathrm{Rh}=\mathrm{H} / \mathrm{Lb} \\
\mathrm{Where}, \mathrm{H}=\text { basin total relief, } \\
\mathrm{Lb}=\text { basin length }\end{array}$ & $\operatorname{Schumm}(1956)$ \\
\hline 22 & Relative relief (Rp) & $\begin{array}{l}\mathrm{Rp}=\mathrm{H} / \mathrm{P} \\
\mathrm{Where}, \mathrm{H}=\text { basin total relief, } \\
\mathrm{P}=\text { the length of the perimeter. }\end{array}$ & \\
\hline 23 & Ruggedness number (Rn) & $\begin{array}{l}\mathbb{R} n=H \times D d \\
\text { Where, } \mathrm{H}=\text { Totle relief } \\
\text { Dd }=\text { drainage density }\end{array}$ & $\begin{array}{l}\text { Melton(1957) and } \\
\text { Strahler(1958) }\end{array}$ \\
\hline
\end{tabular}

Table 2. Stream analysis of river Tapti.

\begin{tabular}{|c|c|c|c|c|c|c|c|c|c|c|}
\hline $\begin{array}{l}\text { Catch } \\
\text { ment }\end{array}$ & $\begin{array}{l}\text { Area, } \\
\text { km }^{2}\end{array}$ & $\begin{array}{c}\text { Perimetr, } \\
\text { km }\end{array}$ & $\begin{array}{l}\text { Strem } \\
\text { Order }\end{array}$ & $\begin{array}{c}\text { No. of } \\
\text { streams } \\
(\mathrm{Nu})\end{array}$ & $\begin{array}{c}\text { Total } \\
\text { stream } \\
\text { length, } \\
\text { Km(Lu) }\end{array}$ & $\begin{array}{l}\text { Mean } \\
\text { stream } \\
\text { length } \\
(\text { Lsm })\end{array}$ & $\begin{array}{c}\text { Stream } \\
\text { Length } \\
\text { ratio } \\
(\mathrm{RL})\end{array}$ & $\begin{array}{c}\text { Bifurcation } \\
\text { ratio }(\mathbf{R b})\end{array}$ & $\begin{array}{c}\text { Mean } \\
\text { Stream } \\
\text { length } \\
\text { ratio } \\
(\text { RLm) }\end{array}$ & $\begin{array}{c}\text { Mean } \\
\text { bifurcation } \\
\text { ratio } \\
(\text { Rbm) }\end{array}$ \\
\hline \multirow[t]{6}{*}{ C 1} & 18473.6 & 995.046 & 1 & 1188 & 3876.83 & 3.26 & 2.20 & 4.17 & 1.97 & 4.25 \\
\hline & & & 2 & 285 & 2046.37 & 7.18 & 1.97 & 3.28 & & \\
\hline & & & 3 & 87 & 1228.50 & 14.12 & 2.30 & 5.12 & & \\
\hline & & & 4 & 17 & 551.50 & 32.44 & 1.71 & 5.67 & & \\
\hline & & & 5 & 3 & 166.41 & 55.47 & 1.67 & 3.00 & & \\
\hline & & & 6 & 1 & 92.53 & 92.53 & - & - & & \\
\hline \multirow[t]{5}{*}{ C 2} & 10530.3 & 1006.08 & 1 & 698 & 1987.05 & 2.85 & 2.30 & 4.34 & 4.89 & 6.11 \\
\hline & & & 2 & 161 & 1052.78 & 6.54 & 1.92 & 3.10 & & \\
\hline & & & 3 & 52 & 654.10 & 12.58 & 1.31 & 4.00 & & \\
\hline & & & 4 & 13 & 214.49 & 16.50 & 14.04 & 13.00 & & \\
\hline & & & 5 & 1 & 231.58 & 231.58 & & & & \\
\hline \multirow[t]{6}{*}{ C 3} & 4997.38 & 671.38 & 1 & 333 & 1043.72 & 3.13 & 2.33 & 4.44 & 2.63 & 4.28 \\
\hline & & & 2 & 75 & 548.78 & 7.32 & 2.56 & 4.17 & & \\
\hline & & & 3 & 18 & 336.77 & 18.71 & 0.38 & 1.80 & & \\
\hline & & & 4 & 10 & 70.36 & 7.04 & 5.83 & 10.00 & & \\
\hline & & & 5 & 1 & 41.04 & 41.04 & 2.03 & 1.00 & & \\
\hline & & & 6 & 1 & 83.36 & 83.36 & & & & \\
\hline \multirow[t]{6}{*}{$\mathrm{C} 4$} & 10176.9 & 974.975 & 1 & 719 & 2217.00 & 3.08 & 1.94 & 4.09 & 2.78 & 4.75 \\
\hline & & & 2 & 176 & 1051.74 & 5.98 & 1.28 & 2.79 & & \\
\hline & & & 3 & 63 & 481.53 & 7.64 & 2.85 & 7.88 & & \\
\hline & & & 4 & 8 & 174.28 & 21.78 & 7.15 & 8.00 & & \\
\hline & & & 5 & 1 & 155.76 & 155.76 & 0.66 & 1.00 & & \\
\hline & & & 6 & 1 & 103.26 & 103.26 & & & & \\
\hline \multirow[t]{6}{*}{ C 5} & 19282.5 & 1368.62 & 1 & 1674 & 4306.34 & 2.57 & 2.38 & 4.57 & 6.66 & 5.98 \\
\hline & & & 2 & 366 & 2242.02 & 6.13 & 0.62 & 1.48 & & \\
\hline & & & 3 & 248 & 935.72 & 3.77 & 8.23 & 15.50 & & \\
\hline & & & 4 & 16 & 497.11 & 31.07 & 0.52 & 5.33 & & \\
\hline & & & 5 & 3 & 48.44 & 16.15 & 21.54 & 3.00 & & \\
\hline & & & 6 & 1 & 347.86 & 347.86 & & & & \\
\hline
\end{tabular}

a defined drain, channel, stream or river at a particular point. The river course according to the topographical features of its run can be divided into five catchments (Fig. 2) (Purna river catchment, Upper Tapi catchment, Middle Tapi catchment, Girna river catchment and Lower Tapi catchment). The catchment has been named based on the major tributary/ contributing river. Morphometric analysis: Morphometry is the measurement and mathematical analysis of the configuration of the Earth's surface, shape and dimensions of its landforms (Clarke, 1966). This analysis can be achieved through measurement of 
Table 3. Morphometric parameters of reiver Tapti.

\begin{tabular}{llccccc}
\hline S. No. & Parameter & C 1 & C 2 & C 3 & C 4 & C 5 \\
\hline 1 & Total basin area km2 (A) & 18473.600 & 10530.300 & 4997.380 & 10176.900 & 19282.500 \\
2 & Basin perimeter,km(P) & 995.046 & 1006.080 & 671.380 & 974.975 & 1368.620 \\
3 & Basin Length,km(Lb) & 202.730 & 274.830 & 118.630 & 246.760 & 353.740 \\
4 & Average width of the basin (Wb) & 91.124 & 38.316 & 42.126 & 41.242 & 54.510 \\
5 & Radius, R of equivqlent area & 76.703 & 57.910 & 39.894 & 56.930 & 78.364 \\
6 & Compactness coefficient of the basin & 2.066 & 2.766 & 2.680 & 2.727 & 2.781 \\
7 & Drainage density (Dd) & 0.431 & 0.393 & 0.425 & 0.411 & 0.434 \\
8 & Drainage texture (T) & 1.589 & 0.919 & 0.652 & 0.993 & 1.686 \\
9 & Stream frequency (Fs) & 0.086 & 0.088 & 0.088 & 0.095 & 0.120 \\
10 & Elongation ratio, (Re) & 0.757 & 0.421 & 0.673 & 0.461 & 0.443 \\
11 & Circulatory ratio (Rc) & 0.234 & 0.131 & 0.139 & 0.134 & 0.129 \\
12 & Length of overland flow (Lg) & 1.160 & 1.272 & 1.176 & 1.216 & 1.151 \\
13 & Constant of channel maintenance (C) & 2.320 & 2.544 & 2.353 & 2.433 & 2.302 \\
\hline
\end{tabular}

Table 4. Relief aspects of Tapti river and sub catchents.

\begin{tabular}{ccccccc}
\hline Catchment & \multicolumn{2}{c}{ Elevation,m } & Relief $(\mathbf{H}-\mathbf{h}) \mathbf{m}$ & Relief $(\mathbf{H}-\mathbf{h}) \mathbf{k m}$ & Longest axis,L & Relief Ratio (H-h)/L \\
\cline { 2 - 3 } & Max.H & Min. $\mathbf{~}$ & & & & \\
\hline Tapi & 1556 & 0 & 1556 & 1.556 & 202.73 & 0.008 \\
C 1 & 1160 & 221 & 939 & 0.939 & 202.73 & 0.005 \\
C 2 & 1163 & 221 & 942 & 0.942 & 202.73 & 0.005 \\
C 3 & 1055 & 150 & 905 & 0.905 & 118.63 & 0.008 \\
C 4 & 1556 & 150 & 1406 & 1.406 & 246.76 & 0.006 \\
C 5 & 1233 & 0 & 1233 & 1.233 & 353.74 & 0.003 \\
\hline
\end{tabular}

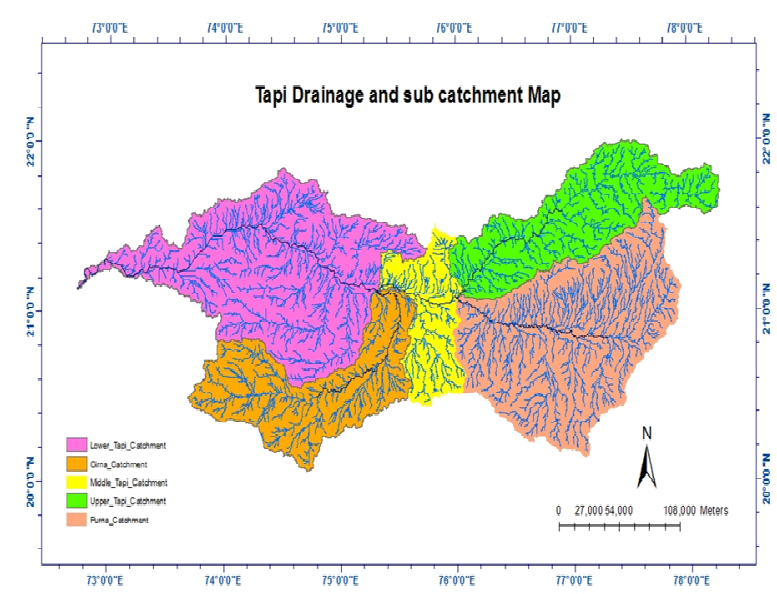

Fig. 2. Tapi river sub-catchments.

linear, aerial and relief aspects of basin and slope contributions (Nag and Lahari, 2011). In the present study, the morphometric analysis for the parameters namely stream order, stream length, bifurcation ratio, stream length ratio, basin length, drainage density, stream frequency, elongation ratio, circularity ratio, form factor, relief ratio, etc. has been carried out using the mathematical formulae given in Table 1 and the results are summarized in Table 3 .

Linear aspect: Stream order, stream length, mean stream length, stream length ratio and bifurcation ratio are linear aspects that were determined and results

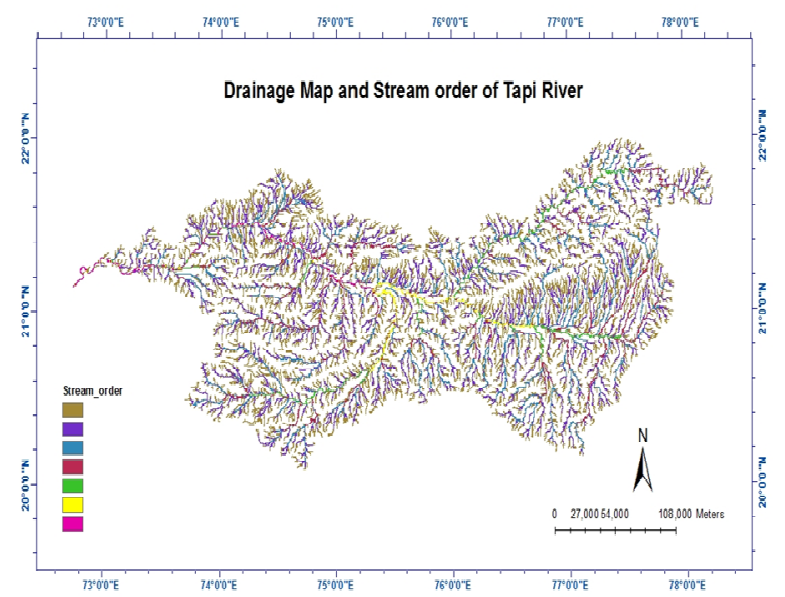

Fig. 3. Stream order of Tapi river.

have been given in Table 2.

Stream order: The designation of stream orders is the first step in drainage basin analysis and is based on a hierarchic ranking of streams. In the present study, ranking of streams has been carried out based on the method proposed by Strahler (1964) (Table 1). It is observed from the Table 2 that the maximum frequency is in case of first order streams. It is also noticed that there is a decrease in stream frequency as the stream order increases. (Fig. 3. catchments showing stream orders, new drainages).

Stream length: The stream length $(\mathrm{Lu})$ has been 


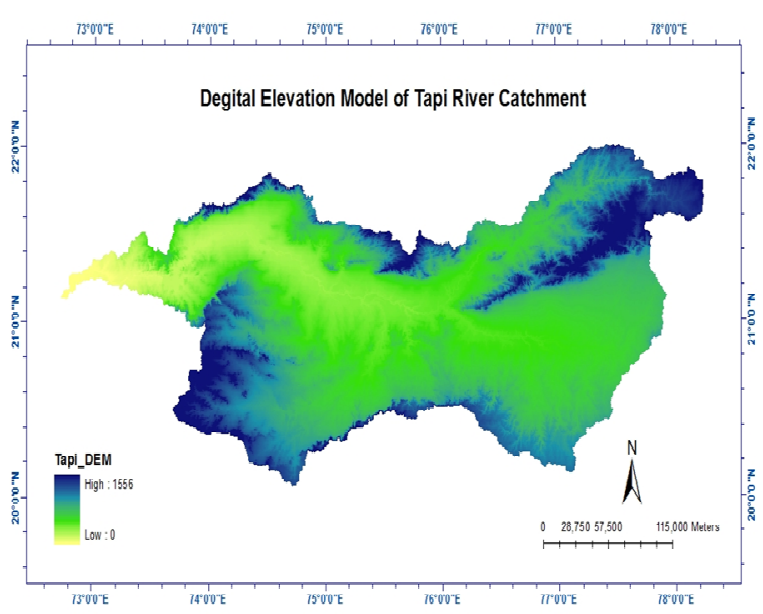

Fig. 4. DEM of Tapi river

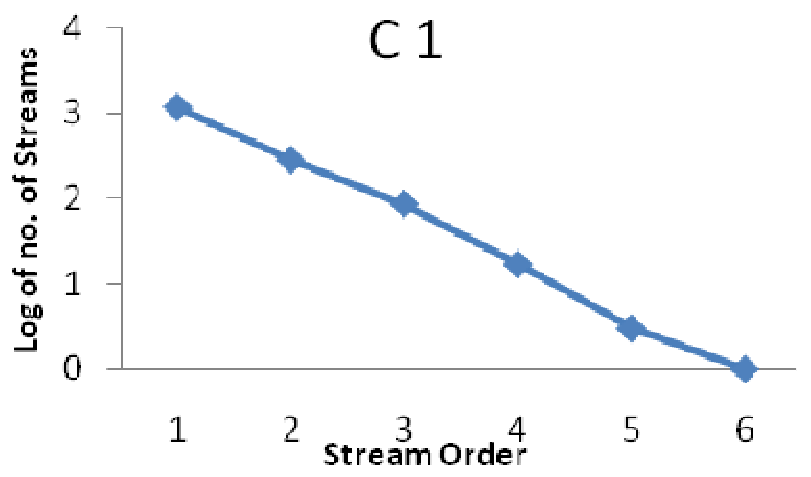

Purna catchment

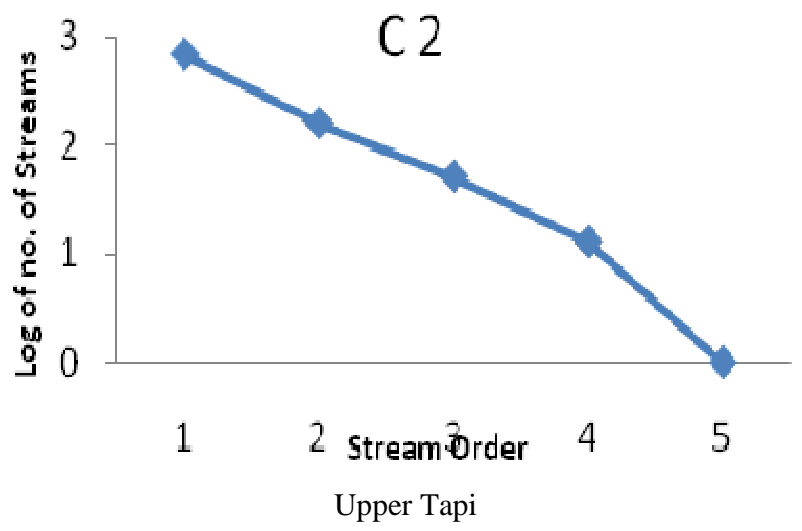

computed based on the law proposed by Horton (1945) for all the catchments (Table 2). Generally, the total length of stream segments is maximum in first order streams and decreases as the stream order increases. Plot of the logarithm of stream length versus stream order (Fig.5) showed the liner pattern which indicates the homogenious rock material subjected to weathering erosion characteristic of the basin

Mean stream length: According to Strahler (1964), the mean stream length is a characteristic property related to the drainage network and its associated surfaces. The mean stream length (Lsm) has been calculated by dividing the total stream length of order ' $u$ ' and number of streams of segment of order ' $u$ ' (Table 1). It is noted from Table 2 that Lsm varies from 2.57 to 347.86 and Lsm of any given order is
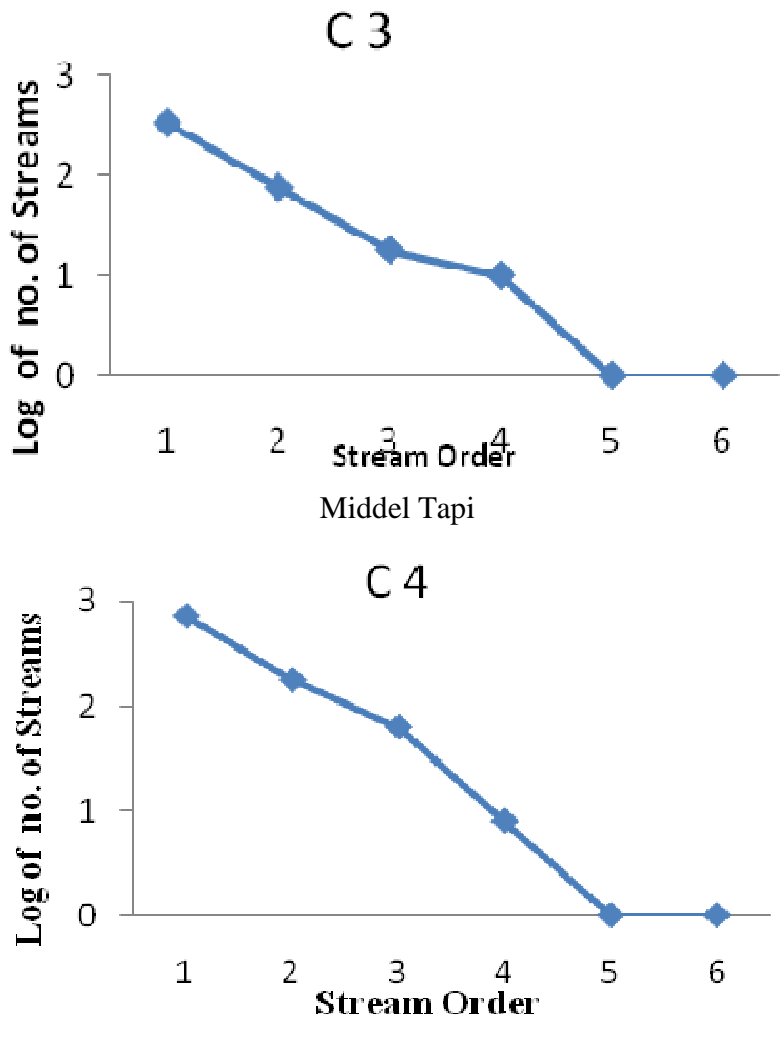

Girna ctchment

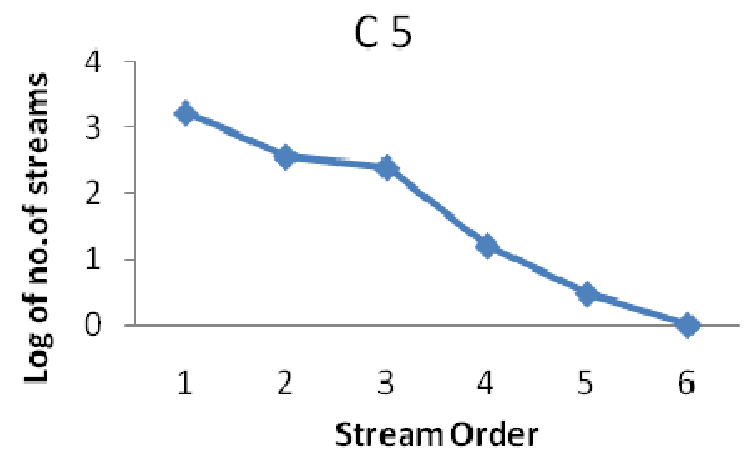

Lower Tapi

Fig. 5. Plots of number of stream segments of each order against order number. 


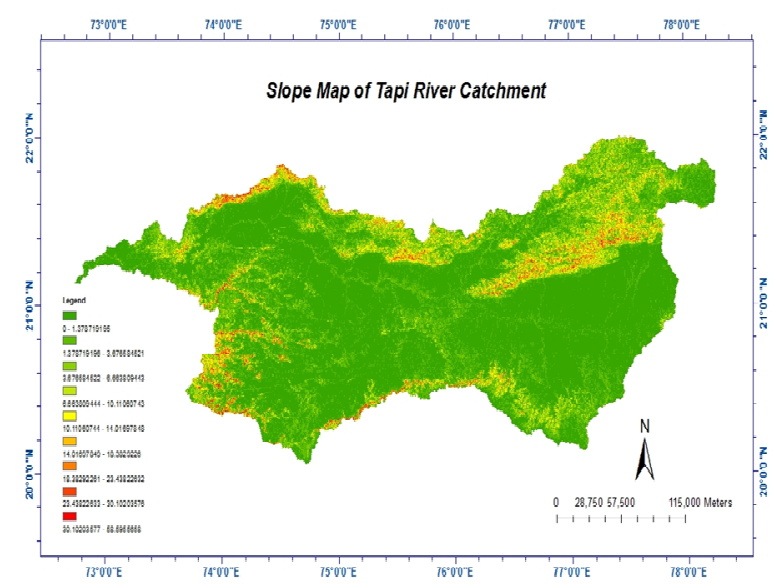

Fig. 6. Slope map of Tapi

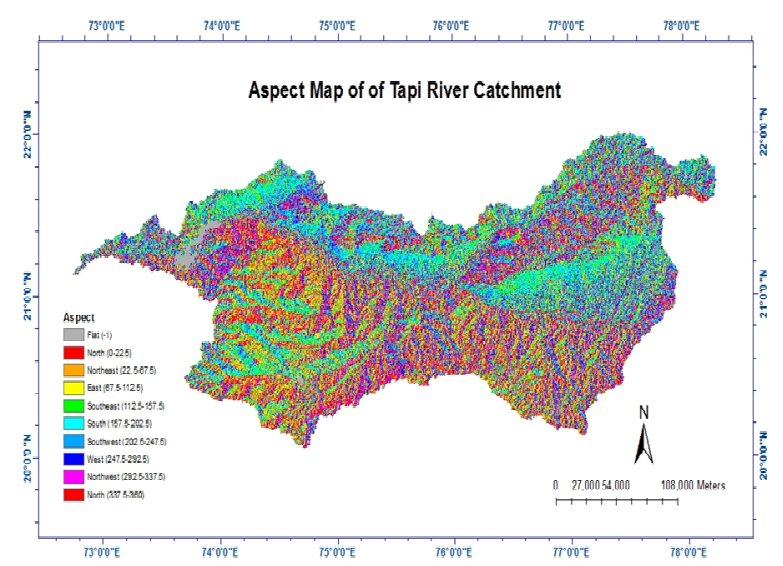

Fig. 7. Aspect map of Tapi river.

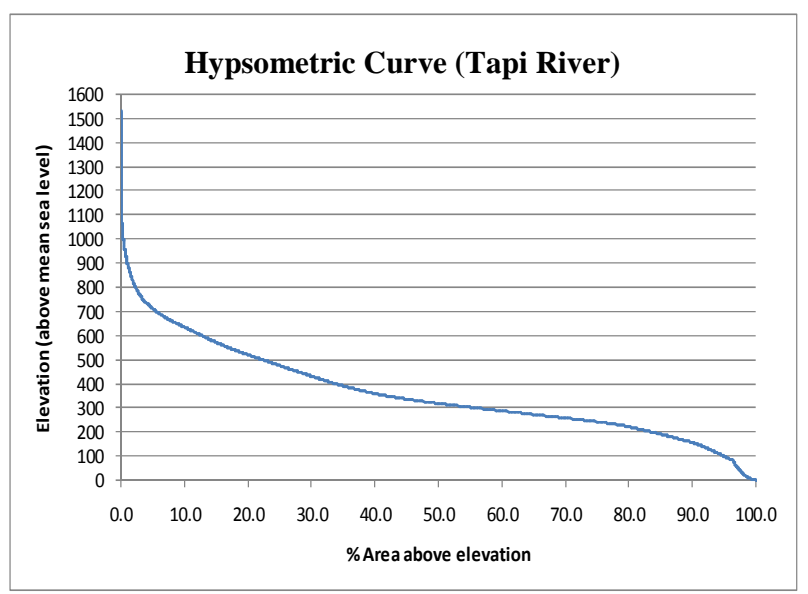

Fig. 8. Hypsometric curve of Tapi river catchment.

greater than that of the lower order and less than that of its next higher order in all the catchments except in Girna catchment which might be due variations in slope and topography.

Stream length ratio: Stream length ratio $(R L)$ may be defined as the ratio of the mean length of the one order to the next lower order of stream segment (Table 1). Horton's law (1945) of stream length states that mean stream length segments of each of the successive orders of a basin tends to approximate a direct geometric series with streams length increasing towards higher order of streams. The RL between streams of different order in the study area reveals that there is a variation in RL in each catchment (Table 2). This variation might be due to changes in slope and topography. Girna and lower Tapi catchment show an increasing trend in the length ratio from lower order to higher order indicating their mature geomorphic stage whereas in remaining catchments, there is a change from one order to another order indicating their late youth stage of geomorphic development (Singh and Singh, 1997).

Bifurcation ratio: The term bifurcation ratio $(\mathrm{Rb})$ may be defined as the ratio of the number of the stream segments of given order to the number of segments of the next higher order (Schumn, 1956) (Table 1). Horton (1945) considered the bifurcation ratio as an index of relief and dissections. Strahler (1957) demonstrated that bifurcation ratio shows a small range of variation for different regions or for different environment except where the powerful geological control dominates. It is observed from the Table 2 , the $\mathrm{Rb}$ is not same from one order to its next order. These irregularities are dependent upon the geological and lithological development of the drainage basin (Strahler, 1964; Farrukh et.al, 2013). The lower values of $\mathrm{Rb}$ are characteristics of the catchment which have suffered less structural disturbances (Strahler, 1964) and the drainage patterns has not been distorted because of the structural disturbances (Nag, 1998). In the present study, the higher values of $\mathrm{Rb}$ indicates strong structural control on the drainage pattern while the lower values indicative of catchment that are not affected by structural disturbances. The mean bifurcation ratio ( $\mathrm{Rbm}$ ) may be defined as the average of bifurcation ratios of all orders (Table 1). In the present case, Rbm varies from 4.24 to 6.10 (Table 2).

Relief aspect: The relief measurements like relief ratio, basin length and total relief are tabulated in Table 2.

Relief ratio: The elevation difference between the highest and lowest points on the valley floor of a catchment is known as the total relief of that catchment. The relief ratio $(\mathrm{Rh})$ of maximum relief to horizontal distance along the longest dimension of the basin parallel to the principal drainage line is termed as relief ratio (Schumm, 1956) (Table 1). According to him, there is direct relationship between the relief and channel gradient. There is also a correlation between hydrological characteristics and the relief ratio of a drainage basin. The $\mathrm{Rh}$ normally increases with decreasing drainage area and size of catchments of a given drainage basin (Gottschalk, 1964). The values of $\mathrm{Rh}$ are given in Table 4 and range from 0.0034 (lower Tapi catchment) to 0.0076 (Middle Tapi catchment). It is noticed that the high values of $\mathrm{Rh}$ indicate steep slope and high relief, while the lower values may indicate the presence of basement rocks that are exposed in the form of small ridges and mounds with lower degree of slope. 
Aerial aspect: Different morphometric parameters like drainage density, texture ratio, stream frequency, form factor, circularity ratio, elongation ratio and length of overland flow have been discussed in detail and are presented in Table 3.

Drainage density: Horton (1932) has introduced drainage density $(\mathrm{Dd})$ to indicate the closeness of spacing of channels. It is defined as the total length of streams of all orders per drainage area (Table 1). Langbein (1947) recognized the significance of Dd as a factor determining the time of travel by water and he also suggested a drainage density varying between 0.55 and $2.09 \mathrm{~km} / \mathrm{km}^{2}$ in humid region withan average density of $1.03 \mathrm{~km} / \mathrm{km}^{2}$. According to $\mathrm{Nag}$ (1998) and Ramaiah et al. (2012) low drainage density generally results in the areas of highly resistant or permeable subsoil material, dense vegetation and low relief. High drainage density is the resultant of weak or impermeable subsurface material, sparse vegetation and mountainous relief. Low drainage density leads to coarse drainage texture while high drainage density leads to fine drainage texture. In present study, the drainage density varies between 0.39 and $0.43 \mathrm{~km} / \mathrm{km}^{2}$ indicating low drainage density (Table 3).

Stream frequency: Horton (1932) introduced stream frequency (Fs) or channel frequency which is the total number of stream segments of all orders per unit area (Table 1). Hypothetically, it is possible to have the basin of same drainage density differing in stream frequency and basins of same stream frequency differing in drainage density. Table 2 shows Fs for all catchments of the study area. It is noted that the Fs exhibits positive correlation with the drainage density values of the catchments indicating the increase in stream population with respect to increase in drainage density.

Drainage texture: Drainage texture $(\mathrm{Rt})$ is one of the important concepts of geomorphology which means that the relative spacing of drainage lines. Drainage lines are numerous over impermeable areas than permeable areas. According to Horton (1945), Rt is the total number of stream segments of all orders per perimeter of that area (Table 1). Smith (1950) has classified drainage density into five different textures. The drainage density less than 2 indicates very coarse, between 2 and 4 is related to coarse, between 4 and 6 is moderate, between 6 and 8 is fine and greater than 8 is very fine drainage texture. In the present study the drainage density (Table 3 ) is of very coarse drainage texture.

Form factor: According to Horton (1932), form factor (Rf) may be defined, as the ratio of basin area to square of the basin length (Table 1). From Table 3, it is observed that the $\mathrm{Rf}$ varies between 0.13 (Purna catchment) and 0.44 (Upper Tapi catchment) and thus indicates that the all catchments are elongated with lower values of form factor.

Circularity ratio: It is the ratio of the area of the basin to the area of a circle having the same circumference as the perimeter of the basin (Miller, 1953) (Table 1).
The circularity ratio (Rc) is influenced by the length and frequency of streams, geological structures, land use/land cover, climate, relief and slope of the basin. In the present study, the Rc (Table 3) ranges from 0.12 to 0.23. Except upper Tapi basin (Rc 0.23) catchment have less than 0.14 indicating that they are elongated.

Elongation ratio: Schumm (1956) defined elongation ratio $(\mathrm{Re})$ as the ratio between the diameter of the circle of the same area as the drainage basin and the maximum length of the basin (Table 1). A circular basin is more efficient in the discharge of run-off than an elongated basin (Singh and Singh, 1997). The values of Re generally vary from 0.6 to 1.0 over a wide variety of climatic and geologic types. Values close to 1.0 are typical of regions of very low relief, whereas values in the range $0.6-0.8$ are usually associated with high relief and steep ground slope (Strahler, 1964). These values can be grouped into four categories namely (a) circular ( $>0.9)$, (b) oval (0.9 to 0.8), (c) less elongated $(<0.7)$. The Re of sub- watersheds of the study area varies from 0.50 to 1.04 (Table 3 ). In study Re found in range 0.42 to 0.76 , it reveals that all the catchments are elongated.

Length of overland flow: It is the length of water over the ground before it gets concentrated into definite stream channels (Table 1). This factor basically relates inversely to the average slope of the channel and is quite synonymous with the length of sheet flow to a large degree. The length of overland flow ( $\mathrm{Lg})$ approximately equals to half of the reciprocal of drainage density (Horton, 1945).The results of stream analysis of Tapi river catchment is shown in Table 2.

Hypsometric integral: Tapi basin is bounded in the north by the Satpura range, by Mahadeo hills on the east and Ajanta range and Satmala range on the south and the Arabian sea on the west. The minimum and maximum elevations in the basin range from 0 to $1556 \mathrm{~m}$ above mean sea level (amsl) (Fig.4 \& 8).The hypsometric curve of a catchment represents the relative area below (or above) a given altitude (Fig. 8). A hypsometric curve is essentially a graph that shows the proportion of land area that exists at various elevations by plotting relative area against relative height. These curves have been used to infer the stage of development of the drainage network (Ramu et al.,2012). The Hypsometric integral value is be between 0 to 1 , it gives a hypsometric integral which is defined as the proportion lying below the curve to the total square graph. If the result value is between 0.6 and 1.0, it indicates the youthful state of dissection. If the result value is between 0.35 and0.60, it indicates a naturedly dissected landform and if the result is less than 0.35 , then it indicates an equilibrium or old state of dissection. The formula for calculating the Hypsometric Integral is given below:

$\mathrm{HI}=$ Mean elevation - Minimum elevation / Maximum elevation - Minimum elevation

Result showed that HI for all the sub catchments is 0.50 which indicates the youthful state of dissection. 
Slope: An understanding of slope distribution is essential to control the kinetic energy of flowing water in a channel. The slope map of an area provides data for settlement planning, mechanisation and possibilities of agriculture, deforestation, planning of engineering structures and morpho-conservation practices (Sreedevi et al., 2005). The degree of slope in the Tapi catchment varied from $0^{\circ}$ to $58^{\circ}$ (Figure 9). Higher degree of slope would result in rapid runoff and increase in erosion rate with feeble recharge potential.

Aspects: An aspect generally refers to the direction to which a mountain slope faces. The aspect of slope can make very significant influences on local climatic conditions. This can also have major effects on the soil moisture and the distribution of vegetation cover of any area (Sharma et al., 2012). The aspect map of the Tapi catchment is shown in Figure 10. From the visual interpretation, it is clearly understood that north, north west and south, southwest slopes mainly occur in the Tapi catchment.

\section{Conclusion}

In the present study, remote sensing and GIS have proved to be efficient tool in drainage delineation and updation and this updated drainage has been used for the morphometric analysis. The morphometric analysis of the drainage networks of all 5 catchments exhibited the dendritic to sub-dendritic drainage pattern and the variation in stream length ratio might be due to changes in slope and topography. The variation in values of bifurcation ratio among the catchments is ascribed to the difference in topography and geometric development. The stream frequencies for all catchments of the study exhibited positive correlation with the drainage density values indicating the increase in stream population with respect to increase in drainage density. Drainage density was very coarse texture. The Elongation ratio showed that all the catchments followed the elongated pattern.

\section{REFERENCES}

Biswas, S., Sudhakar, S. and Desai, V. R.(1999). Prioritization of sub watersheds based on morphometric analysis of drainage basin - A remote sensing and GIS approach. Journal of Indian Society Remote Sensing, 27(3): 155 -166 .

Clarke, J. I. (1966). Morphometry from Maps. Essays in Geomorphology. Elsevier Publ. Co., New York, pp. 235-274.

Farrukh, A., Gowhar, M. and Romshoo, S. R. (2013). Morphometric analysis to infer hydrological behaviour of lidder watershed, western himalaya, India. Hindawi Publishing Corporation, Geography Journal, Article ID 178021,pp 14.

Gottschalk, L.C. (1964). Reservoir Sedimentation. In: V.T. Chow (Ed.), Handbook of Applied Hydrology. McGraw Hill Book Company, New York, Section 7-I.

Horton, R. E. (1932). Drainage basin characteristics. Transactions American Geophysical Union., 13: 350-361.
Horton, R. E. (1945). Erosional development of streams and their drainage basins; hydrophysical approach to quantitative morphology. Geological Society of America Bulletin., 56: 275-370.

Kanth, T. A. and Hassan, Z. (2012). Morphometric analysis and prioritization watersheds for soil and water resource management In Wular Catchment using Geo-Spatial Tools. International Journal of Geology, Earth and Environmental Sciences, 2(1): 30-41.

Langbein, W. B. (1947). Topographic characteristics of drainage basins. U.S. Geol. Surv. Water-Supply Paper, 986(C): 157-159.

Miller, V. C. (1953). A quantitative geomorphic study of drainage basin characteristics in the clinch mountain area, virginia and tennessee, Proj. NR 389-402, Tech Rep 3, Columbia University, Department of Geology, ONR, New York.

Mishra, A. K. and Rawat, K. S. (2012). Morphometric analysis of moolbari watershed in Sub-Himalayan Region of India: A Remote Sensing and GIS Approach. Journal of soil water conservation, 11(2): $144-153$.

Nag, S. K. (1998). Morphometric analysis using remote sensing techniques in the chaka sub-basin, Purulia District, West Bengal. Journal of Indian Society Remote Sensing,26(1 and 2): 69-76.

Nag, S. K. and Lahari, A. (2011). Morphometric analysis of Dwarakeswar watershed, Bankura district, West Bengal, India, using spatial information technology. International Journal of Water Resources and Environmental Engineering,3 (10):212-219

Ramaiah, S. N., Gopalakrishna, G. S., Vittala, S. Srinivasa and Najeeb, K. Md.(2012). Morphometric analysis of sub-basins in and around Malur Taluk, Kolar District, Karnataka using remote sensing and GIS Techniques. International Quarterly Scientific Journal, 11(1): 89-94.

Ramu and Mahalingam, B. (2012). Hypsometric properties of drainage basins in Karnataka using geographical information system. New York Science Journal, 5 (12):156-158.

Schumm, S.A. (1956). Evolution of drainage systems and slopes in badlands at Perth Amboy, New Jersey. Geological Society of America Bulletin, 67: 597-646.

Sharma, T., Jaglan, M. S., Singh, O. and Kumar, S. (2012). Morphometric characterisation of Tangri watershed in lower siwalik and piedmont zone of Haryana and Punjab. Hydrology Journal,35(3\&4):94-110

Singh, S. and Singh, M. C. (1997). Morphometric analysis of Kanhar river basin. National Geographical. Journal of India, 43(1): 31-43.

Smith, K. G. (1950). Standards for grading textures of erosional topography. American Journal of Science, 248: 655-668.

Sreedevi, P. D., Subrahmanyam, K. and Shakeel, A. (2005). The significance of morphometric analysis for obtaining groundwater potential zones in a structurally controlled terrain. J. Environ. Geol. 47, 412-420.

Strahler, A. N. (1957). Quantitative analysis of watershed geomorphology. Transactions American Geophysical Union, 38:913-920.

Strahler, A.N. (1964). Quantitative geomorphology of drainage basins and channel networks. In: V.T. Chow (ed), Handbook of Applied Hydrology. McGraw Hill Book Company, New York, section 4-II.773. 